\title{
IMPLEMENTING FOREST TENURE REFORMS: PERSPECTIVES FROM INDONESIA'S FORESTRY AGENCIES
}

\author{
Tuti Herawati ${ }^{12^{*}}$, Esther Mwangi ${ }^{3}$, and Nining Liswanti ${ }^{2}$ \\ ${ }^{1}$ Directorate General of Social Forestry and Environmental Partnerships, \\ The Ministry of Environment and Forestry, Republic of Indonesia, Jakarta, Indonesia \\ ${ }^{2}$ Centre for International Forestry Research - Jalan CIFOR Bogor, West Java, Indonesia \\ ${ }^{3}$ Centre for International Forestry Research (CIFOR) Nairobi, Kenya
}

Received: 16 November 2018, Revised: 15 Septembr 2019, Accepted: 28 October 2019

\begin{abstract}
IMPLEMENTING FOREST TENURE REFORMS: PERSPECTIVES FROM INDONESIA'S FORESTRY AGENCIES. Forest Tenure Reform implementation involves diverse actors with multiple roles and interests, more importantly government officials. Few studies have attempted to systematically document the conditions faced by government agency implementers in their efforts to implement forest tenure reforms. This study attempts to identify factors that enhance or hamper reform implementation from the perspective of individual implementers both at national and sub-national levels in Indonesia. The study was conducted through analysing data resulted from interviewing bureaucrats who were purposively selected at Central and Local Governments. Most interviewees indicated that forest tenure reforms have three interrelated objectives, i.e.: to conserve forests and restore degraded forests, to improve community livelihoods and ensure benefits are equitably distributed; and to secure the rights of access to locals, forestadjacent or forest-dwelling communities. Reform implementation has been effective or somewhat effective in protecting community rights to access, use, manage and benefit from forests. Close to half of the respondents indicated that their activities gave special consideration to low income groups but few paid special attention to women and women's rights. Main constraints in implementation are inadequate budgets and insufficient manpower to execute tenure-related activities. Divergent priorities between national and sub-national/local levels and changes in government that redistribute personnel are additional factors that hinder reform implementation. Overall, respondents agree that reforms are only partially implemented due to technical and institutional constraints, which in turn influence the extent to which collaboration/ coordination among actors can be achieved and the extent to which community tenure needs such as conflict management and resolution can be addressed.
\end{abstract}

Keywords: Bureaucrat analysis, forest tenure, implementation, constraint, gender, conflict

IMPLEMENTASI REFORMASI TENURLAL KEHUTANAN: PERSPEKTIF DARI BIROKRAT PELAKSANA PROGRAM. Program reformasi pengelolan butan melibatkan banyak pibak dengan masing-masing peran dan kepentingannya, terutama birokrat pemerintah. Penelitian tentang peran birokrasi di dalam reformasi tenurial masih sangat terbatas. Studi ini mengkaji pelaksanaan program reformasi tenurial dari perspektif individu pelaksana di tingkat nasional dan sub-nasional di Indonesia. Penelitian dilakukan melalui wawancara responden yang dipilih dari birokrat di tingkat Pemerintah Pusat dan Daerah. Data dianalisis secara deskriptif kualitatif untuk mendalami aspek internal faktor birokrat pelaksana, penilaian mereka terhadap pelaksanaan program dan faktor penghambat serta pendukungnya. Sebagian responden menyatakan babwa program reformasi tenurial butan secara umum ditujukan untuk melestarikan atau memulibkan butan yang rusak meningkatkan pengbidupan masyarakat, dan menjamin bak akses masyarakat yang bergantung pada sumber daya butan. Pelaksanaan program dinilai telah efektif dalam melindungi bak-bak masyarakat untuk mengakses, menggunakan, mengelola, dan mengambil manfaat dari butan. Responden juga menunjukkan babwa mereka telah memberikan perhatian khusus kepada kelompok. berpenghasilan rendah tetapi hanya sedikit yang memberikan perhatian khusus pada kelompok perempuan. Kendala utama untuk. pelaksanaan program terdiri dari; 1) keterbatasan anggaran; 2) kurangnya tenaga pelaksana; 3) prioritas yang berbeda antara nasional dan sub-nasional; dan 4) personil birokrat yang cepat berubah posisi. Secara keseluruban, responden menyatakan bahwa sebagian (51-70\%) program reformasi tenurial butan di Indonesia telah berhasil diimplementasikan. Upaya penyelesaian konflik sebagai persoalan dasar dalam

${ }^{*}$ Corresponding author: njpnapitu@gmail.com 
program reformasi tenurial dapat ditingkatkan melalui koordinasi dan kolaborasi diantara para pelaku program termasuk antar sektor di pemerintahan dan mitra pembangunan.

Kata kunci: Analisis birokrasi, tenurial butan, implementasi, kendala, gender

\section{INTRODUCTION}

Indonesia's forest area covers around 121 million ha (MoEF, 2016) or about 63\% of Indonesia's total land area, which is 190 million ha (FAO, 2015). Over the past three decades, the forestry sector has been a key part of the economic development agenda of Indonesia. Based on the 1967 Foreign and Domestic Investment Act (No. 1/1967) and Forestry Act (No. 5/1967), the Ministry of Environment and Forestry (MoEF) allocated about 60 million ha of available state forests for timber production, either through concessions for logging (Hak Pengelolaan Hutan/ HPH) or industrial timber plantation (Hutan Tanaman Industri/HTI).

Based on Global Forest Resource Assessment/FRA (FAO, 2010, 2015), Indonesia was reported having the second highest rate of deforestation among tropical countries. The level of deforestation has been verified periodically since 1990 with the highest level of deforestation rates recorded during the period of 1996 to 2000, at 3.51 million hectares per year (MoEF, 2018). Several factors have contributed to deforestation, including excessive logging (Hidayat et al., 2018); infrastructure development (Sloan et al., 2018); development of oil palm plantations and forest fires (MoEF, 2018). Beyond that, the underlying factors are the corruption of the political and economic system (FWI, 2015); the weakness of forest governance (FWI, 2015); and inadequate mechanisms and resources for law enforcement (Hidayat, 2016) mainly on tenurial conflicts (Hall, 2013; Herawati, Hubert, Rohadi, Banjade, \& Fay, 2017; Siscawati et al., 2017).

Therefore, an adaptive governance, adaptive management, and participatory learning are strategic approaches in governance reform to achieve sustainable forest management (Larson
\& Dahal, 2012; Nugroho, van der Veen, Skidmore, \& Hussin, 2017). Forest policy in Indonesia has increasingly shifted from a more centralized, state-based management to more community-based forest management. This shift has gradually devolved forest management to local and customary communities (Siscawati et al., 2017). Recently this devolution has shown sign of accelerating, as the national policy of government of Indonesia supports improved implementation of both agrarian and forest tenure reforms.

This forest tenure reform, well known as social forestry program refers to the latest legislation i.e. Minister of Environment and Forestry Regulation No.83 of 2016 (result of revision and integration of various former social forestry rules). The Minister of Environment and Forestry takes the lead in implementing forest tenure reform. At the sub-national level, the ministry's implementing unit agency works collaboratively with the Forestry services under the authority of the local government in each province (Herawati, Liswanti, Banjade, \& Mwangi, 2017). In more detail, Forest Management Unit, under the Forestry Office, plays a significant role as the main parent in the implementation of the Social Forestry program in Indonesia.

The first momentum of Indonesia's forest tenure reform is still debatable. Some of the key players in the forestry community consider that reform started in 1999 with enaction of the Forestry Law No. 41. The 1999 Forestry Law is very different from the previous one (Law No.5/1976), by providing more rooms for community participations in forestry governance (Colfer \& Resosudarmo, 2012). The current legal and regulatory framework of forest governance provides considerable 
opportunity for advancing forest tenure reform implementation by allocating 12.7 $\mathrm{M}$ ha of forest land for social forestry (De Royer, Van Noordwijk, \& Roshetko, 2018; MoEF, 2018). There are five schemes in the social forestry program i.e. community forest (Hutan Kemasyarakatan), village forest (Hutan Desa), community-based timber plantation (Hutan Tanaman Rakyat), partnership (Kemitraan) and customary forest (Hutan Adat) (Banjade, Herawati, Liswanti, \& Mwangi, 2016; Herawati, Liswanti, et al., 2017; Siscawati et al., 2017).

Forest tenure reform involves diverse actors with multiple roles and interests, including government officials (Blanc et al., 2018; Zhang \& Putzel, 2016). Over the past 30 years, numerous studies in Indonesia have examined these reforms from diverse angles e.g. community participation (Djamhuri, 2008; Kusumanto \& Sirait, 2012; Suharti, 2001); community livelihood (Barr et al., 2006; Maryudi et al., 2012); social capital in supporting community forestry (Lee, Rianti, \& Park, 2017; Wulandari \& Inoue, 2018); and sustainable forest management (Mendoza, 2000; Purnomo, Mendoza, \& Prabhu, 2005; Santika et al., 2017; Tiani \& Charancle, 2007). At the global level a number of studies indicating forest tenure reforms play a critical role in resource management, as evidenced by for example, granting of forest rights in Nepal (Devkota \& Mustalahti, 2018; Fox, 2018; Maharjan, 2005), implementing land formalization policy in Africa (Boone, 2019) and in Malagasy (Boué \& Colin, 2018); provision of certificate of ownership in Mexico (De Janvry, Emerick, Gonzalez-Navarro, \& Sadoulet, 1993; Sellars \& Alix-Garcia, 2018). Similarly, household land distribution in China is convincing as an effective forest and land resource management (Tan, Wang, \& Heerink, 2018; Zinda \& Zhang, 2018). However, few studies have attempted to systematically document the conditions faced by government agency implementers in multiple settings in their efforts to reform forest tenure.

Many previous studies point to a role of government in reforms, but also identify its weaknesses in capacity. Some of these studies often fail to dig deeper to parse out root causes or to explore the set of positive and negative stimuli and incentives faced by government agencies and implementers charged with such a sensitive and highly contentious mandate. Because of this incomplete analysis the range of possible solutions is limited and mostly inadequate. This study aimed to generate insights into the underlying processes and factors that influence implementation of tenure reforms. Specifically, it identifies factors that enhance or constrain reforms from the perspective of individual implementers in government agencies at national and sub-national levels.

\section{MATERIAL AND METHOD}

\section{A. Study Site}

This study was conducted at the national and sub-national levels. The central government officials were selected purposively within the Ministry of Environment and Forestry who are responsible for forest tenure reform. At the subnational level, the respondents were selected from provincial and district Government. As part of the Global Comparative Study on Tenure (GCS-Tenure) project, the study was conducted in Lampung, Moluccas and South Sulawesi Province. Lampung Province and South Sulawesi were selected as sample sites that have conducted forest tenure reform programs with considerable progress. Moluccas was chosen as an example of a site where forest tenure reform programs are still at early stages.

\section{B. Methods}

A purposive method was used in selecting respondents, targeting those who have legal mandate in implementing forest tenure reform in the relevant organization. This survey was mainly targeted to mid and high position government officials, with a minimum level as head of division. The total respondents were 28 whom were interviewed personally from November 2016 to February 2017. The 75\% of the interviewees were male and $25 \%$ were female and majority of the interviewees were 


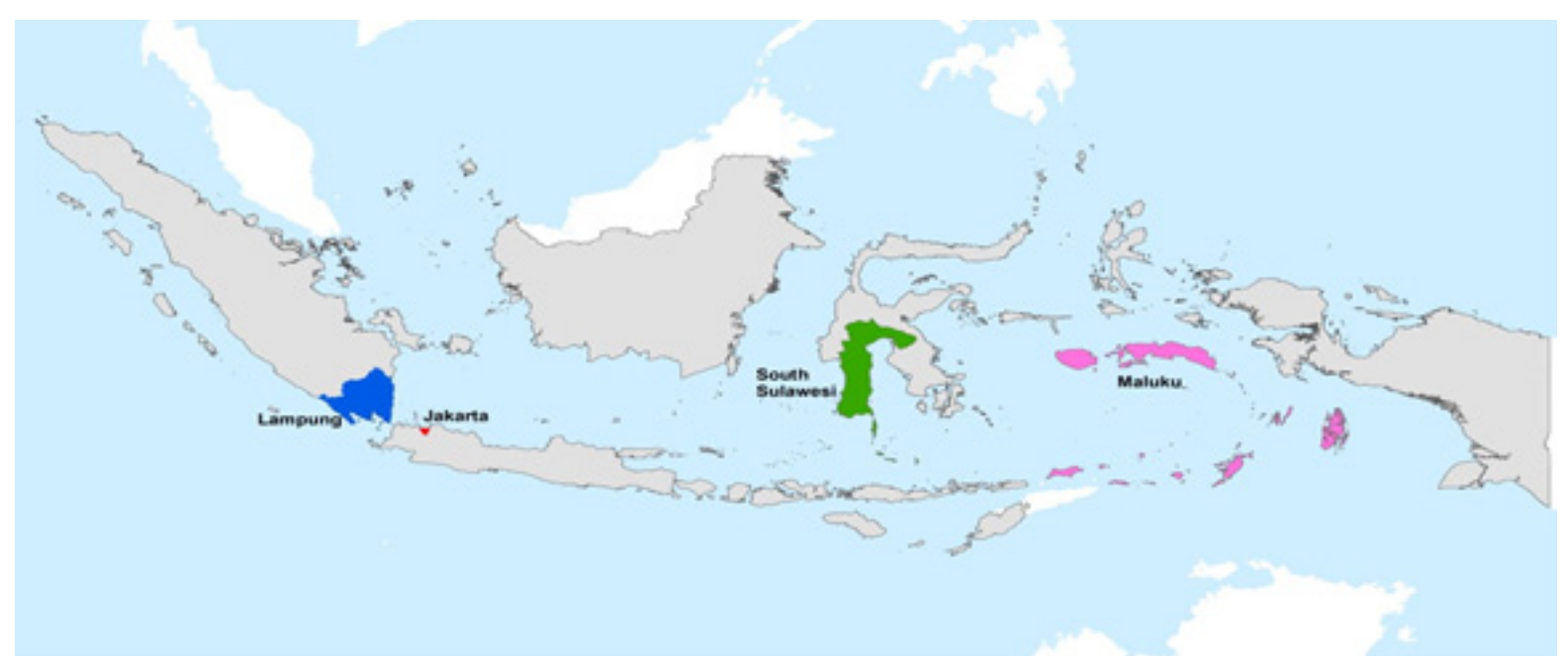

Figure 1. Study site of implementation of forest tenure reforms in four Provinces (Jakarta, Lampung, South Sulawesi, and Moluccas)

from subnational $(64 \%)$ compared to national $(36 \%)$ level. Potential respondents were identified through series of discussion during the project consultations with key informants from Ministry of Environment and Forestry. The interviews were mostly conducted at respondent's office during working hour. The interviewer used paper-based questioner and electronic tools for data input. The discussions were also recorded by permission from the interviewee. The shortest time for an interview process was 2 hours, but sometimes longer, up to 4 hours depending on the situation and additional information provided by respondents.

The survey inquired multiple reforms or implemented laws that are related such as forest tenure reform, land tenure or agrarian reform, regional autonomy and decentralization. While it targeted key individuals responsible for implementing a specific law, the individuals were also asked for their views on other laws to the extent that they are implicating implementation of their primary reform or law.

The interviews which used a structured questioner aimed to understand roles and responsibilities of government implementing agencies, the challenges faced during reform implementation, and their priorities, aspirations, expectations, and capabilities. The study also examined institutional arrangements to implement the reforms including extent of coordination and collaboration between relevant actors. In addition, the study also analysed gender aspect such as who are the target beneficiaries of the program, whether they give special consideration for woman group and gender norm in social aspect that may facilitate or hinder. The interviewees were asked also to provide a self-assessment of the extent to which reform has been implemented and what needs to be done to improve implementation. A full guideline including set of questioner is available online https://data. cifor.org/file. xhtml?fileId=1766\&version $=$ RELEASED\&version=.0) in the "Securing Tenure Rights for Forest-Dependent Communities: Implementing agency surveys in Peru, Uganda, Nepal and Indonesia" (Herawati \& Mwangi, 2017).

The survey was designed for Open Data Kit and deployed for data collection through mobile applications using ONA platform1.

\footnotetext{
1 ONA is a social enterprise that builds the data infrastructure to drive change. Using mapping and data technologies from its namesake mobile survey platform, ONA also builds mobile apps such as OpenSRP, which helps frontline health workers deliver services more effectively to rural families. The mapping work, referenced in TIME, is, an innovative approach to support precision service delivery
} 


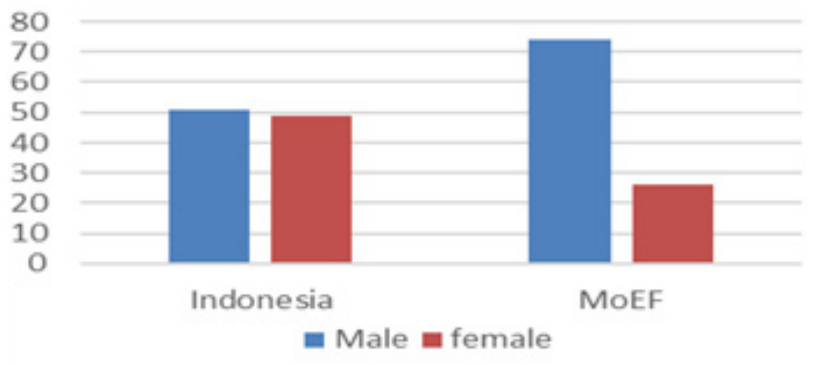

Figure 2. Gender composition on Government officials overall in Indonesia and in MoEF Source: MoEF (2016)and BPS (2017)

An Android-based tablet version of a complex interview was developed and successfully validated. Use of tablets may be costlier than paper for small samples and less costly for large studies (Giduthuri et al., 2014). Beside for collecting interview data surveys, this technology was proven valid to be applied for community-based forest monitoring (Devries, Pratihast, Verbesselt, Kooistra, \& Herold, 2016; Pratihast et al., 2014).

\section{Analysis}

Once the survey was completed, data was downloaded from ONA server for analysis. The data from ONA was pre-processed in $\mathrm{R}$ program using ONA R-package. All the data were analyzed using descriptive statistics mainly by calculating its percentage through Exploratory Data Analysis (EDA) approach. Open-ended and closed-ended questions were both coded. Closed-ended variables that had many questions were re-coded into broader groups using a transformation tool in SPSS software. Coding was done for open ended questions and closed ended questions that had many options.

Exploratory Data Analysis (EDA) is the general descriptive analysis statistics done on the entire dataset but most importantly, to the variables that directly answer our research questions. The exploratory analysis covered three aspects of the data which are; background information of implementing agency comprising gender composition, skill and knowledge; general information related to forest tenure reform, and assessment of forest tenure reform and its constraints. The techniques used in EDA consisted of cross tabulation summaries, scatterplots, bar graphs and histograms. This was done to maximize insight into a data set, uncover underlying data structure, extract important variables and detect outliers or anomalies and to test underlying assumptions.

\section{RESULT AND DISCUSSION}

\section{A. Gender, Knowledge, Skills and Capacity of Implementing Agency Officials}

Three-quarters of the respondents were male, even though women have similar tasks and responsibilities in implementing the program. This finding is unsurprising as the forestry sector is commonly perceived as a male dominated sector (Elias et al., 2018; Gurung \& Lama, 2003). Although data on the overall gender composition of Indonesia's government officials shows a fairly good balance between women and men, the MoEF is highly skewed with 74\% men and 26\% women (Figure 2). Table 1 shows the dominance of male in mid to highest level of government officials career (BPS, 2017).

\section{B. Reform Types, Objective and Target Beneficiaries}

The forest tenure reform in Indonesia under social forestry has introduced five 
Tabel 1. Composition of male and female staff on the mid to high position levels

\begin{tabular}{lccc}
\hline No & Position & Male (person) & Female (person) \\
\hline 1. & Echelon V & 10.206 & 4.908 \\
2. & Echelon IV & 220.193 & 148.304 \\
3. & Echelon III & 66.845 & 51.507 \\
4. & Echelon II & 14.002 & 10.928 \\
5. & Echelon I & 610 & 382 \\
\hline
\end{tabular}

Source: BPS. (2017)
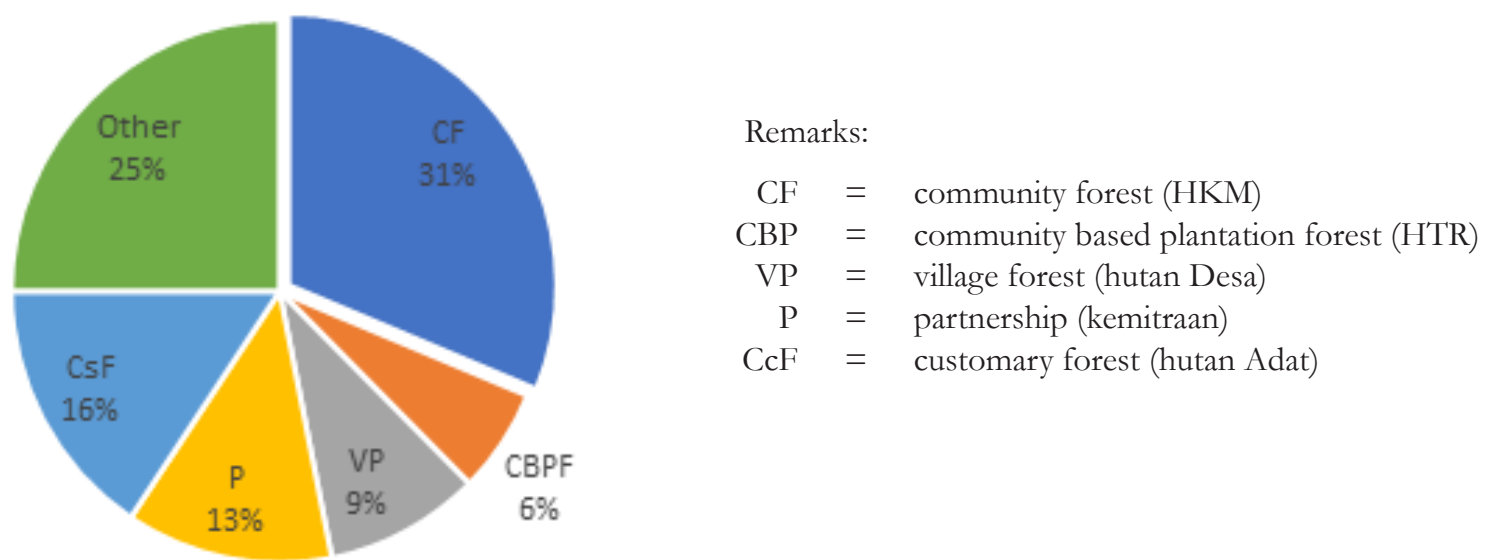

Figure 3. Proportion of respondents based on implementing forest tenure reform

schemes, i.e. community forest (Hutan Kemasyarakatan/HKM), village forest (Hutan Desa/HD), community based plantation forest (Hutan Tanaman Rakyat/HTR), partnership (Kemitraan) and customary forest (Hutan Adat) HA) (Figure 3).

Study shows that most respondent $(75 \%)$ directly implement all types of forest tenure reforms on the ground. Specifically, 31\% implements on community forestry (HKM); $6 \%$ community-based plantation forest, $9 \%$ village forestry, 13\% partnership and 16\% customary forestry schemes. The remaining $25 \%$ support regional planning and forestry development as they are the main stakeholders with high level of power and influence for implementing forest tenure reform.

Respondents mentioned "Forest tenure and right" and "Community Forestry" as the main thematic areas in which they had worked during the previous year (Figure 4). No respondent mentioned gender mainstreaming aspect, which suggests forest tenure reform in Indonesia relatively has not yet focused on this issue.

The objectives of forest tenure reforms range from securing the tenure rights of communities and supporting community access to conserving the forest (including restoring degraded forests) and improving community livelihood. Twenty one percent $(21 \%)$ of the respondents reported that reforms were crafted in response to secure tenure rights of community; $20 \%$ indicated that reforms sought to support community access, use and management of forest lands, $16 \%$ indicated that the reforms sought to conserve forest including restoring degraded forest, and $13 \%$ noted that they sought to improve livelihoods of local community and ensure that benefits from forest resources are equitably distributed among local communities (Figure 5).

The study found that the target beneficiaries were categorized as $41 \%$ for local communities, $22 \%$ for local government and $12 \%$ for 


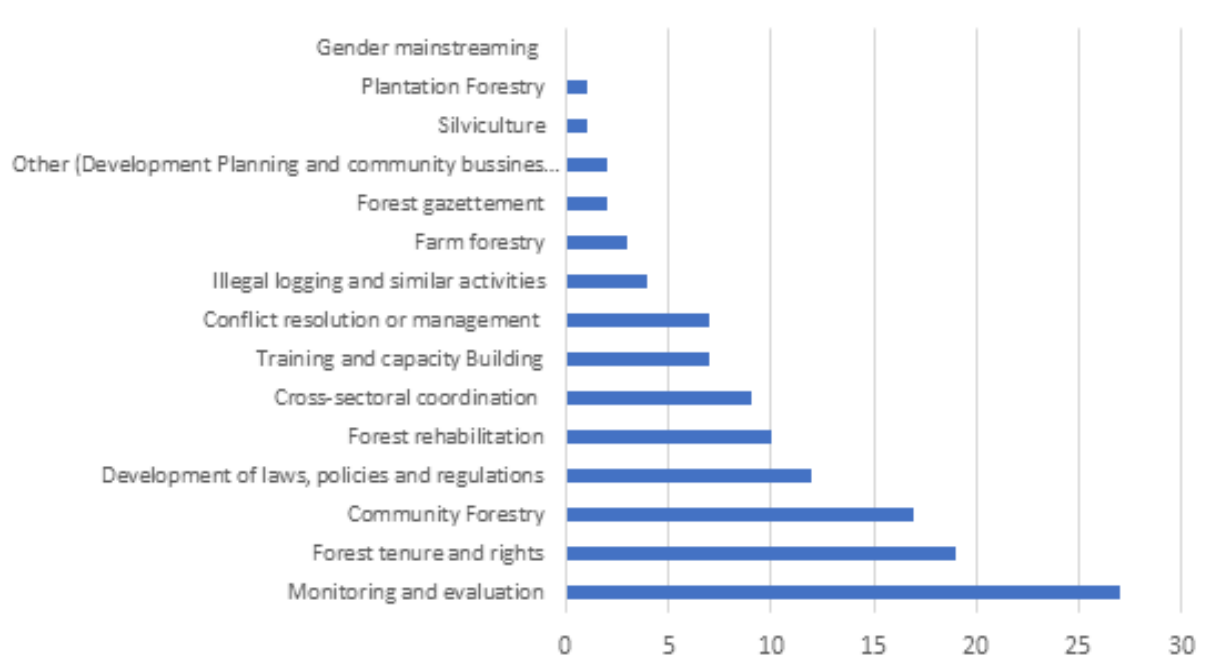

Figure 4. Thematic area of bureaucrats' activities

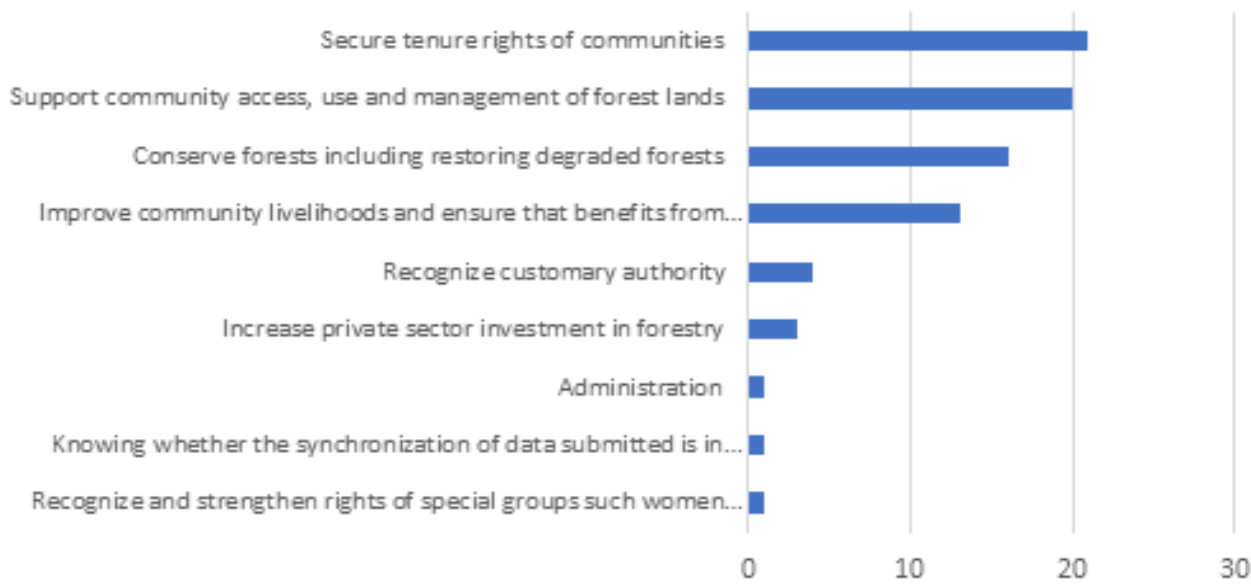

Figure 5. Objectives of forest tenure reforms

private sector (Figure 6). Only $9 \%$ and $7 \%$ of correspondents said that the reforms targeted non-governmental organizations (NGOs), the poor, and women respectively. This in turn indicated that most activities would very likely have targeted local communities in general. Most implementers targeted local communities but did not disaggregate them into constituent groups. Greater disaggregation is required as it helps to better address the needs and priorities of social groups, which are often different.

\section{Assessment of Forest Tenure Reform Implementation}

The implementers were asked about main tenure problems faced by community they serve. Figure 7 shows that government officials perceived illegal settlement or land invasion, land allocation to private companies and illegal cultivation in forests as the most widespread tenure problems faced by communities. The case of land allocated to private companies causing conflict between the local community and company in many places where logging 


Remarks:
- Communities
- Local governments
- Private sector actors
- NGOs
- The poor
- Women
- Other government agencies

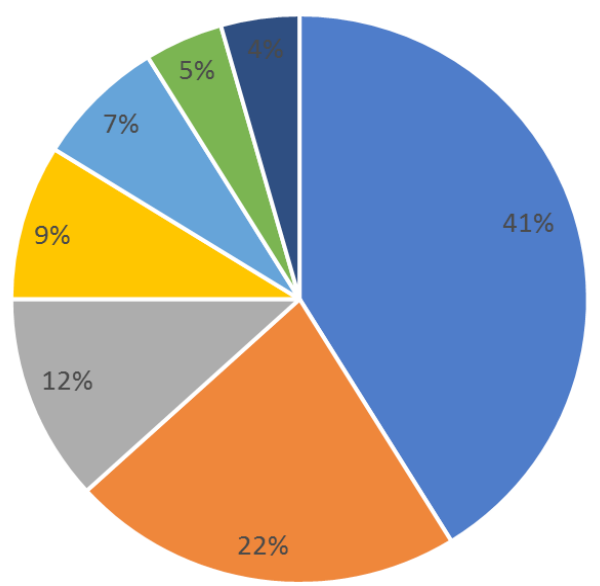

Figure 6. Target beneficiaries of forest tenure reforms

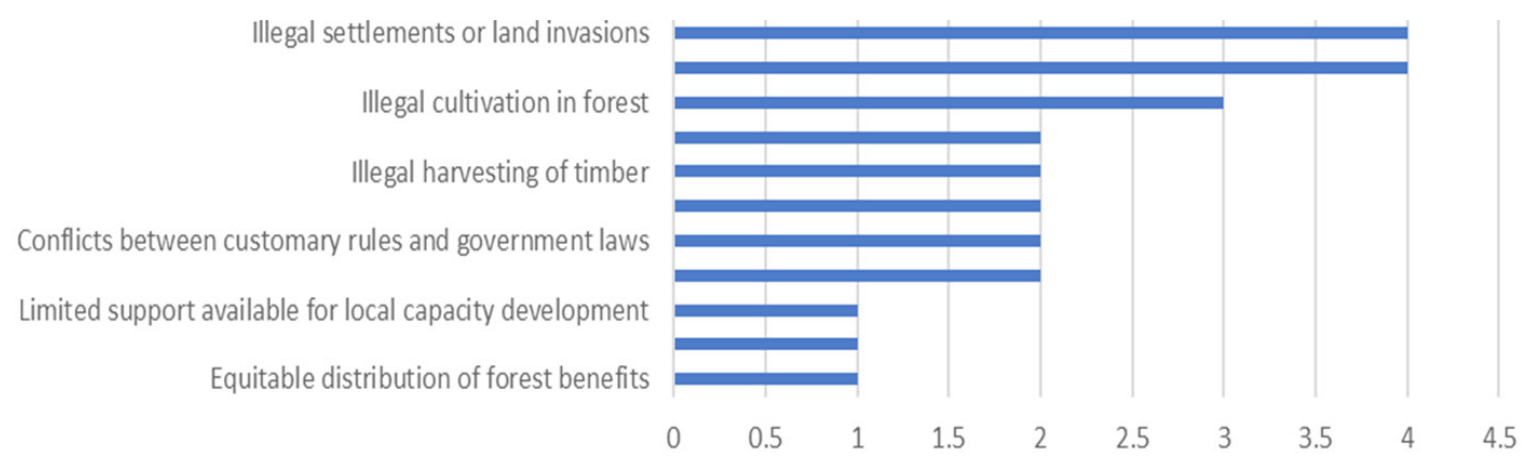

Figure 7. Tenure related needs and problems faced by community based on bureaucrat's perception (Notes the scale presenting score of priority)

companies and plantation concession operated. In Maluku province, the study found the most common problem in the community was inconsistent boundary demarcation between state forest and customary territory. In addition in Maluku, overlapping individual claims within a customary territory leads to conflicts over boundaries within community. Several studies (Liswanti, 2007; Siscawati, 2017) indicate that overlapping boundaries among customary territories and incompatibility/ mismatch between maps used as a reference in determining the object of forest tenure reform with real situation in the field has become an inhibiting factor for the acceleration of forest tenure reform in Indonesia.

Implementers have taken several measures to safeguard community rights (Figure 8).
They educate or inform communities on their rights under the law to overcome illegal activities. They also clarify boundaries through consultation and mapping, and work closely with customary or traditional leaders, while coordinating with agriculture, lands, and other sectors to minimize threats and to anticipate potential tenure conflicts.

Figure 9 illustrates assessment of implementers for achievement of each objective. According to respondents, the objective of supporting communities' access, use and management of forest land were mostly achieved. Securing community tenure rights and conserving forest, including restoring degraded forests and improving community livelihood, were also mostly achieved. Ultimately, support for community access, use and forest was the 


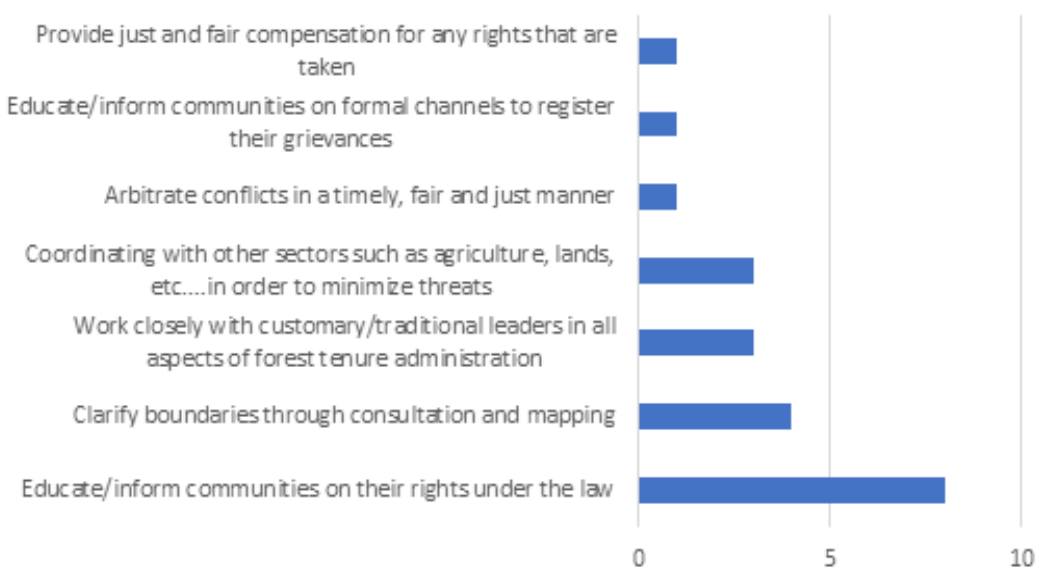

Figure 8. Measures to safeguard community rights

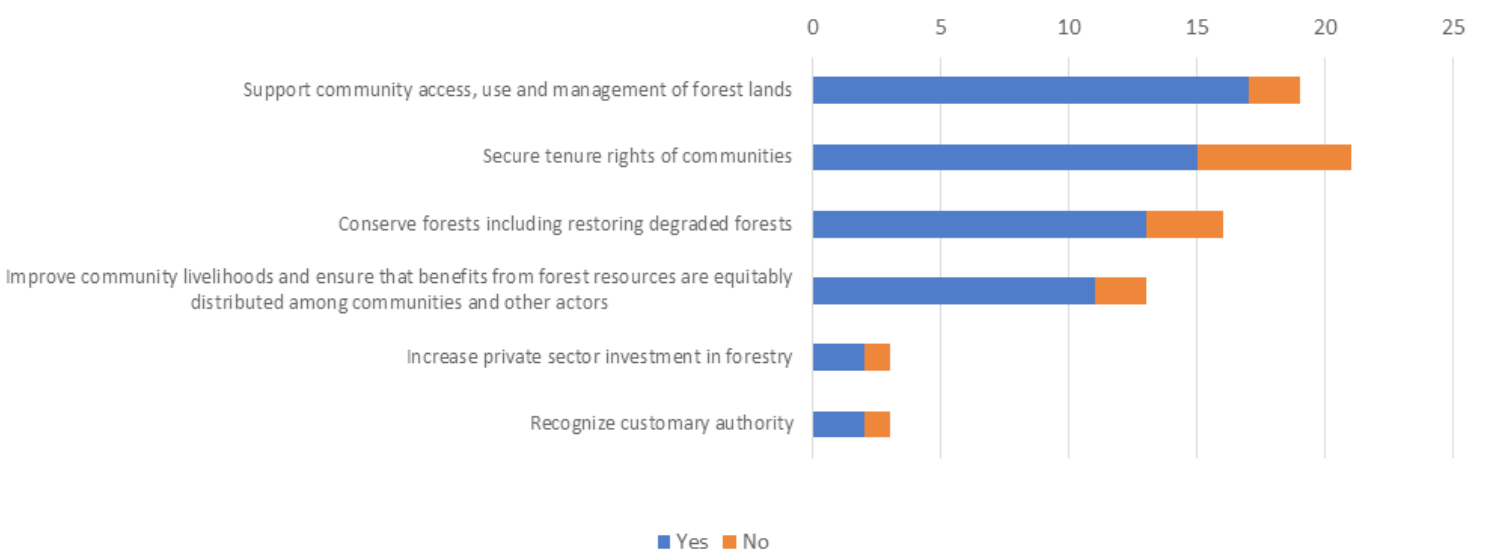

Figure 9. Implementers' assessment of objective of forest tenure reform achievement

greatest achievement, as many stakeholders including the President of the Republic Indonesia, support forest tenure reform as part of Nawacita- the current President's vision on Indonesia's development. This political view has led to increase in total area of forest that can be accessed and used by community.

More than half $(53 \%)$ of government officials viewed activities to implement reforms as somewhat effective, while $29 \%$ and $11 \%$ said they were effective to very effective, and only $7 \%$ mentioned they were not effective (Figure 10). Figure 11 identifies how respondents perceive the effectiveness of activities (Figure 11).

Those who argue "very effective" achievement (91-100\%) mention the strong legal foundation for community to secure their access and right.

"It can be considered very effective in providing community access, because there is no opportunity for other actors to manage that specific area. The farmers have strong basis for legality and are highly confident on their right of forest land. In addition to that, if we give them full right such as in customary forest, there is a risk that the community will face threat for land trading. The high risk for community on losing their livelihood resources is expressed." (pers.com, 2016).

The few who said that reform implementation was effective or very effective indicated that nearly all activities had been implemented as planned. Most cases of tenure conflict had been resolved. Those who said that implementation was somewhat effective, indicated about half 


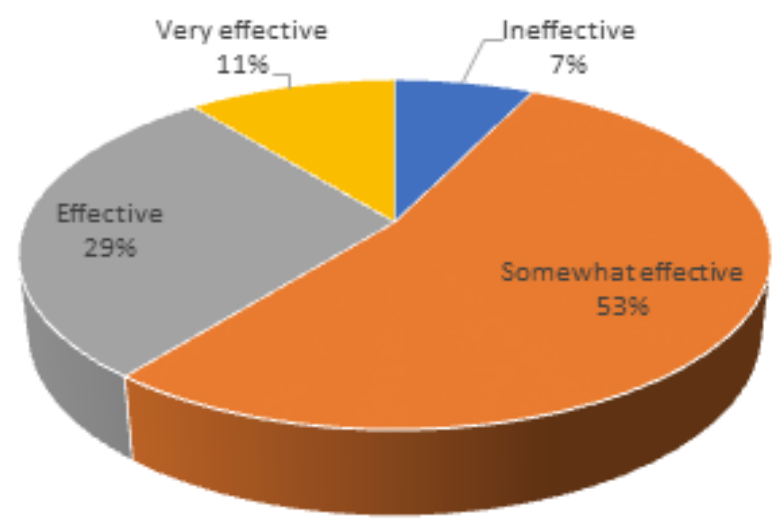

Figure 10. Effectiveness of tenure reform implementation activities

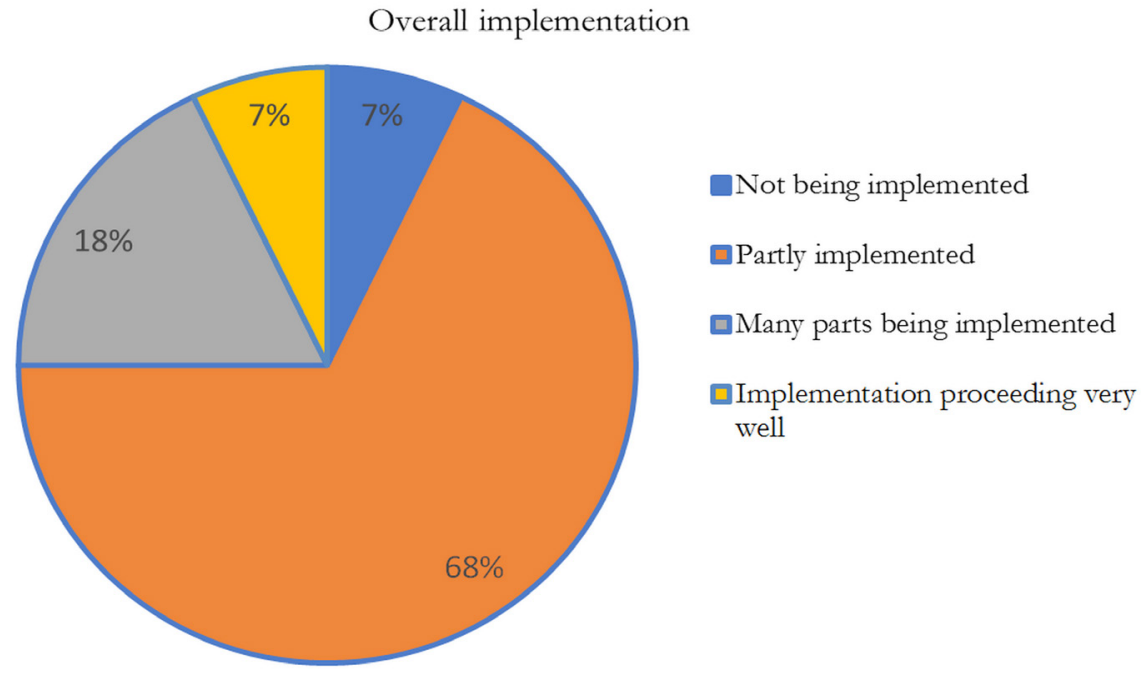

Figure 11. Overall implementation of forest tenure reform

of activities were completed. For example, in the case of HKm half of the previous year's allocation targets were licensed and thus achieved. Those who said that reforms were not effective worked primarily in divisions that had only been operating for two years.

In terms of the overall forest tenure reform implementation, most respondent $(68 \%)$ stated it was partly implemented; $18 \%$ said many part being implemented; $7 \%$ said it was not being implemented and the rest, 7\% saw implementation proceeding very well. Most respondents compare target against achievement. At national level, they refer to the target of last period (2001-2014) which planned to allocate $2.5 \mathrm{M}$ ha of forest for the community but unfortunately only achieved less than $1 \mathrm{M}$ ha (pers.com, 2016). Moreover, they do not feel confident of achieving the new national target of $12.7 \mathrm{M}$ ha in 2019.

\section{Forest Tenure Reform Constraints}

The top four constraints to reform implementation were: lack of knowledge on rights and policies both at community level and at government officials supporting the implementation, in particular from other related sectors; an onerous process to obtain permits; inadequate budgets and lack of sufficient human resource to execute initiatives (Table 2). Banjade et al., (2015) also noted the registration process as an enormous constraint to implement reforms. 
The respondents reported that economic, social and political factors affected the implementation of tenure reforms (Figure 12). Most importantly, economic factors negatively affected implementation of various activities. The bureaucrats dealt with the problem of inadequate budgets and poverty in the community. To address poverty at community level, tenure reform is intended to enhance household incomes. Some respondents mentioned that budget allocation is related to national economic priorities, which have recently more focused on infrastructure development. Conversely, MoEF rank, 17 out of 34 ministries or about $0.8-1.2 \%$ of state revenue and expenditure budget.

Customary practice, authority and ethnicity were reported to be the major social factors affecting reform implementation (Figure 13). Communities insist that forests belong to them and are agitating for full ownership. They feel that participating in social forestry program legitimise state authority on their land. All respondents reported that religious practice and gender norms are not constraining factors.

About a third of respondents both at national and sub national levels reported that politicians interfered much more than they supported reform implementation (Figure 14). According to respondents at sub national level, some politicians pressure bureaucrats to provide community members with right and access to land in order to buy votes. Change in government structure were also reported to influence the implementation of forest tenure reforms. This issue is related to positioning the right man/woman in the right position at the right time.

Table 2. Main constraints/obstacles in forest tenure reform in Indonesia

\begin{tabular}{cll}
\hline Rank & Main Constraints/ obstacles & Score \\
\hline 1 & Lack of knowledge on rights and policies & 1.61 \\
2 & Onerous process to obtain a permit that requires years to complete & 1.25 \\
3 & Inadequate budgets & 1.25 \\
4 & Lack of sufficient human resources to execute initiatives & 1.25 \\
\hline
\end{tabular}

Note: the scale was calculated based on its frequency and weighting system within the factor

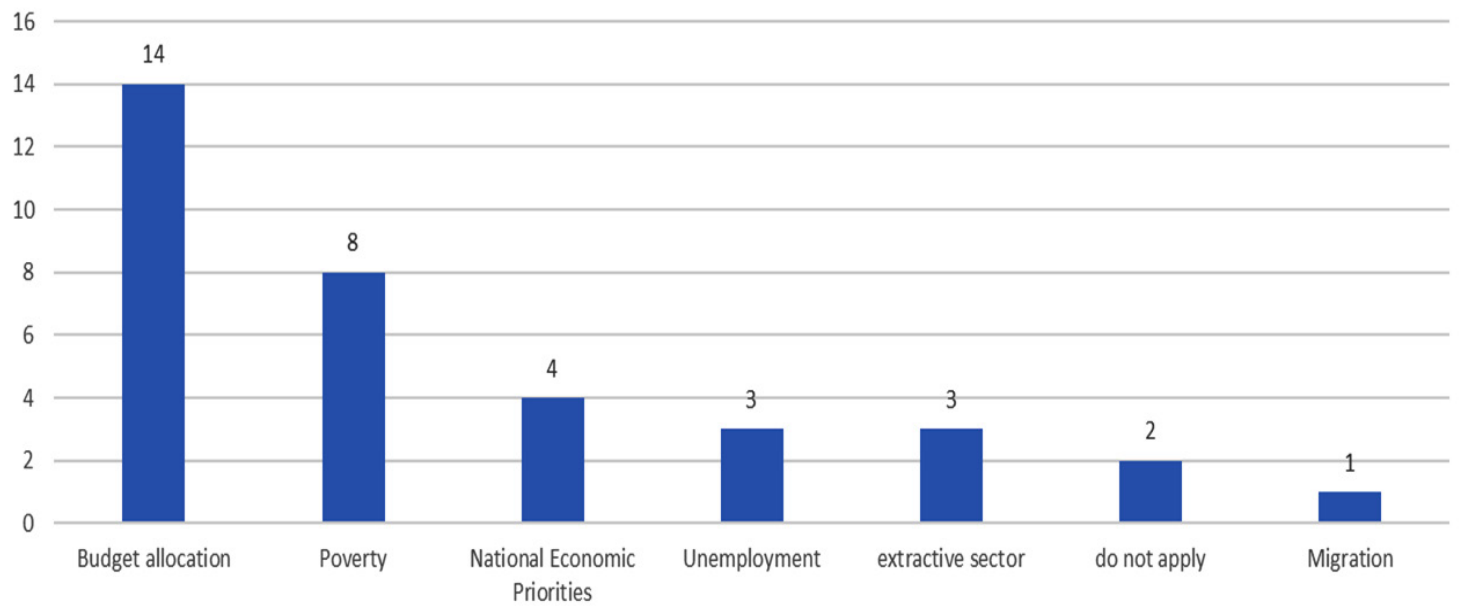

Figure 12. Economic factors that have affected implementation of forest tenure reforms 


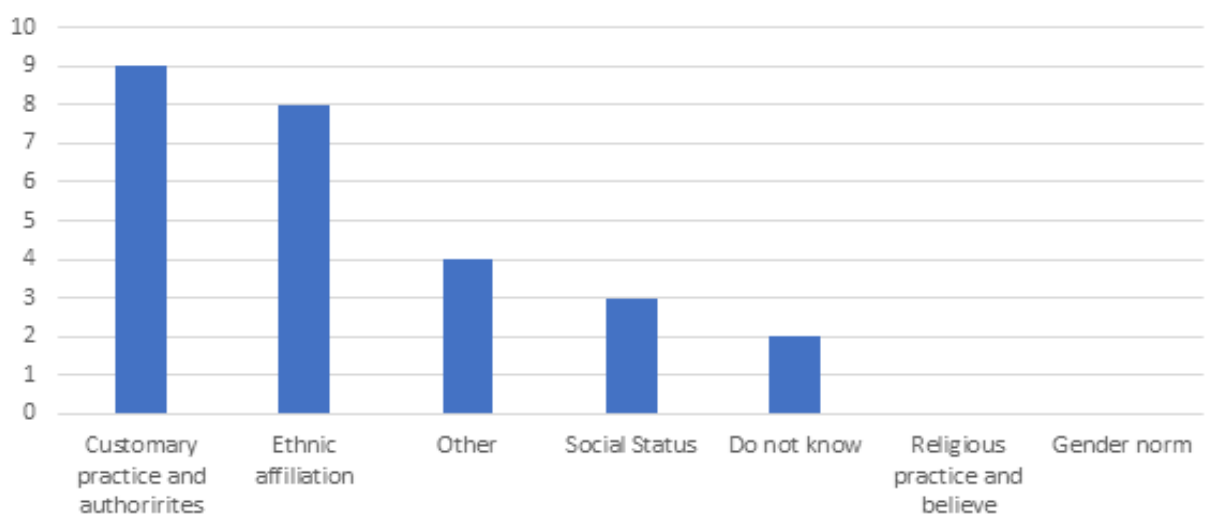

Figure 13. Social factors that constraint or hinder forest tenure reform implementation

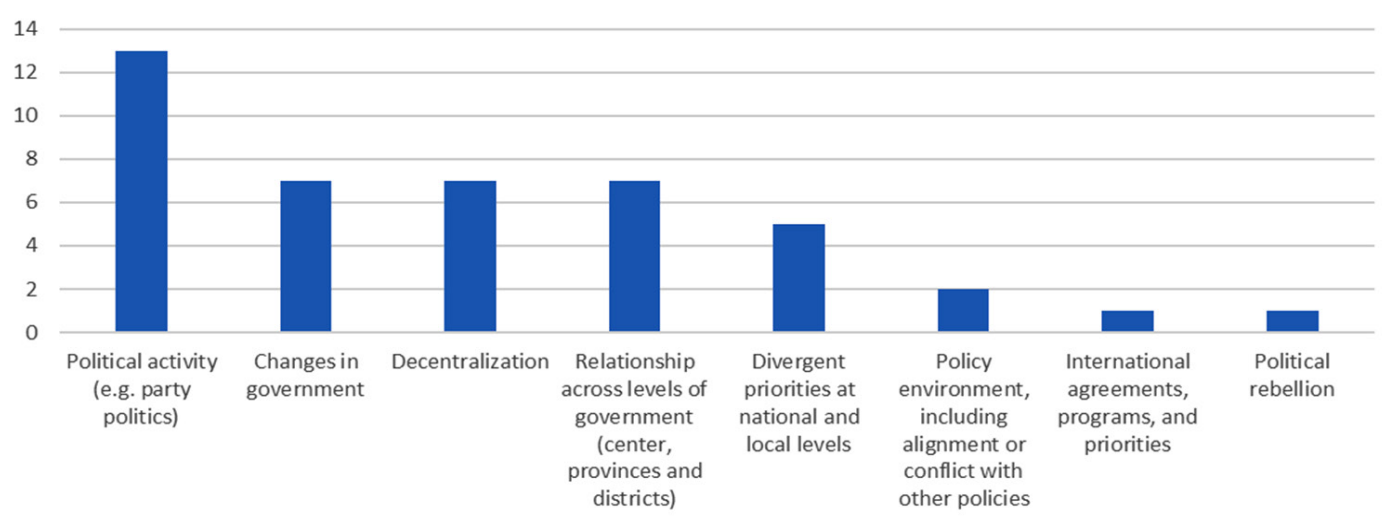

Figure 14. Political factor that constraint or hinder forest tenure reform implementation

\section{CONCLUSION}

The study revealed that political, economic and social factors influencing bureaucrats in implementing forest tenure reforms. Some bureaucrats have a mandate to implement social forestry as they work for organizations that have long been in charge of this program. Other bureaucrats work for organizations established about two-three years ago after the revamping and restructuring due to merger of the Ministry of Forestry and Ministry of Environment in 2014. Even though their organizational structure is new, bureaucrats who implement forest tenure reforms at national level are knowledgeable or well informed about tenure issues. Although these organizations have just been established, it does not become a problem for them to continue the program. Individually, most bureaucrats clearly support community access on forest land to support livelihoods, while respecting the need to conserve and rehabilitate degraded forest. They are also clear on targeted beneficiaries, although attention to women and marginalized groups has not been particularly prominent.

Economic factors are the primary factors limiting allocation of development budgets and influencing the level of poverty at community level. Although social forestry is on the agenda of the current president to encourage land access and rights of the community, respondents reported that budget support for this activity is still insufficient. Forestry is not among the top ten of national priorities. Indeed, budget allocation for MoEF ranked 17 out of 34 ministries. 
Social factors are also reported as obstacles to implementation of forest tenure reforms when dealing with indigenous or customary communities. The strong claims of indigenous peoples over forest lands as ancestral heritage cause them to reject government claims on forest lands. Implementation is constrained by a lack of legitimacy and acceptance of the reforms by communities. They view themselves as full owners of the forests that they occupy and reject the partial rights offered by more longstanding social forestry schemes.

Most of the bureaucrats think that reform implementation is somewhat effective, having only partial implementation of reform activities and partial achievement of targets. This level of effectiveness can be linked to low availability of budgets. This, in turn, reflects the low priority of forestry in the development agenda at both national and sub-national levels compared to other sectors. Onerous processes for licensing and registration are another limiting factor. Lack of knowledge of policies and laws and lack of sufficient human resources to execute reforms may, however, limit the impact of these positive shifts.

Most implementers targeted local communities but did not disaggregate them into constituent groups. Greater disaggregation is required as it helps to better address the needs and priorities of social groups, which are often different. The customary rights of indigenous groups have gained currency in the past five years given the constitutional court rulings and a presidential decree. Gender differentiation needs similar attention to recognize the different needs of women and men. Although Indonesia has a Ministry of Woman's Empowerment and Child Protection and has signed several treaties on gender equality, forestry continues to be male-dominated.

\section{ACKNOWLEDGEMENT}

We are grateful to the European Commission, the Global Environment Facility, the International Fund for Agricultural
Development and the UN Food and Agriculture Organization for supporting this work. Thanks, are also due to Mia Siscawati for invaluable input, Mani Ram Banjade for discussing during respondent determination and other CIFORGCS Tenure team in Peru, Nepal, and Uganda. We thank to Safia Agrawal and Mark Foss who provided valuable input on language editing.

\section{REFERENCES}

Banjade, M. R., Herawati, T., Liswanti, N., \& Mwangi, E. (2016). Introduction tenure reform in Indonesia when? what? why? CIFOR Infobrief no. 163, 1-8. CIFOR, Bogor. doi://10.17528/cifor/006333.

Barr, C., Resosudarmo, I. A. P., Dermawan, A., McCarthy, J., Moeliono, M., Setiono, B. (2006). Decentralization of forest administration in Indonesia: implications for forest sustainability, economic development and community livelihoods. Center for International Forestry Research (CIFOR). doi.org://10.17528/cifor/002113.

Blanc, S., Lingua, F., Bioglio, L., Pensa, R., Brun, F., Mosso, A., ... Mosso, A. (2018). Implementing participatory processes in forestry training using social network analysis techniques. Forests, 9(8), 463. doi://10.3390/f9080463.

Boone, C. (2019). Legal empowerment of the poor through property rights reform: Tensions and trade-offs of land registration and titling in Sub-Saharan Africa. The Journal of Development Studies, 55(3), 384-400. doi://10.1080/00220 388.2018 .1451633$.

Boué, C., \& Colin, J.-P. (2018). Land certification as a substitute or complement to local procedures? Securing rural land transactions in the Malagasy highlands. Land Use Policy, 72, 192-200. doi://10.1016/J. LANDUSEPOL.2017.12.049

BPS. (2017). Jumlah pegawai Negeri Sipil menurut jenis kepegawaian dan jenis Kelamin, Desember 2013 dan Desember 2016. Retrieved from https://www.bps. go.id/statictable/2015/09/08/1798/ jumlah-pegawai-negeri-sipil-menurut-jeniskepegawaian-dan-jenis-kelamin-desember2013-dan-desember-2016.html on December 9, 2018. 
Colfer, C., \& Resosudarmo, I. (2012). Which way forward:people, forests, and policy making in Indonesia \&- Carol J. Pierce Colfer - Google Buku. Resource for the Future, Centre for International Forestry Researach, Institute of Southeast Asian Studies. Retrieved from https://books. google.co.id $/ \mathrm{s}$ ?hl=id\&lr=\&id=BuWsH9ax FEMC\&oi $=$ fnd \&pg $=$ PR $1 \& d q=$ devolutio $\mathrm{n}+$ in + indonesia\&ots $=\mathrm{xAHgg} 18 \mathrm{jn} 9 \& \operatorname{sig}=$ N74N6kCIx1 K2bwf7ri-x9_K2z10\&redir_ esc $=\mathrm{y} \#_{\mathrm{v}}=$ onepage $\& \mathrm{q}=$ devolution in indonesia\&f=false on February 8, 2018.

De Janvry, A., Emerick, K., Gonzalez-Navarro, M., \& Sadoulet, E. (1993). Delinking land rights from land use: Certification and Migration in Mexico †. American Economic Review, 105(10), 3125-3149. doi.org://10.1257/aer.20130853.

S. De Royer, M. Van Noordwijk, and J.M. Roshetko. (2018). "Does community-based forest management in Indonesia devolve social justice or social costs?," International Forestry Review, 20(2), 167-180, (1 June 2018). doi://10.1505/146554818823767609 crawler=true\&mimetype $=$ application $/$ pdf.

Devkota, B. P., \& Mustalahti, I. (2018). Complexities in accessing REDD+ benefits in community forestry: evidence from Nepal's Terai region. International Forestry Review, 20(3), 332-345.

Devries, B., Pratihast, A. K., Verbesselt, J., Kooistra, L., \& Herold, M. (2016). Characterizing forest change using community-based monitoring data and landsat time series. PLOS ONE, 11(3) doi://10.1371/journal.pone.0147121.

Djamhuri, T. L. (2008). Community participation in a social forestry program in Central Java, Indonesia: the effect of incentive structure and social capital. Agroforestry Systems, 74(1), 83-96. doi://10.1007/s10457-008-9150-5.

Elias, M., Elmirst, R., Ibraeva, G., Sijapati Basnett, B., Ablezova, M., \& Siscawati, M. (2018). Understanding gendered innovation processes in forest-based landscapes: case studies from Indonesia and Kyrgyz Republic. Retrieved from https://cgspace.cgiar.org/ handle/10568/96185 on March 19, 2018.

FAO. (2006). Time for action changing the gender situation in forestry report of the team of specialists on gender and forestry. Roma. Retrieved from http:// www.fao.org/forestry/10952-0dc39dc097e5 44f4dbe8167fb9b62ea99.pdf on March 13, 2018.
FAO. (2010). Global forest resource assessment 2010. Rome. Retrieved from http://www.fao. org/3/a-i1757e.pdf on March 13, 2018.

FAO. (2015). Global forest assesment 2015. Retrieved from hhtp://www.fao.org on March 13, 2018.

Fox, J. (2018). Community forestry, labor migration and agrarian change in a Nepali village: 1980 to 2010. The Journal of Peasant Studies, 45(3), 610-629. doi://10.1080/03066150.2016.124 6436.

FWI. (2015). The state of forest report in indonesia the condition, problems and challenges Brussels. Brussel. Retrieved from http:// ec.europa.eu/environment/forests / pdf/ conf_26_05_2014/Session 1/Christian Purba.pdf on March 14, 2018.

Giduthuri, J. G., Maire, N., Joseph, S., Kudale, A., Schaetti, C., Sundaram, N., ... Weiss, M. G. (2014). Developing and validating a tablet version of an; illness explanatory model interview for a public health survey in Pune, India. PLoS ONE, 9(9), e107374. doi://10.1371/journal.pone.0107374.

Gurung, J. D., \& Lama, K. (2003). Incorporating gender into a male domain: the approach of a forestry project in Nepal 1. Unasylva (Vol. 212). Retrieved from http://www.fao.org/docrep/pdf/007/ y5382e/y5382e16.pdf on February 8, 2018.

Hall, R. (2013). REDD+ and the underlying causes of deforestation and forest degradation. (Ronnie Hall, Ed.). Asuncion, Paraguay: Global Forest Coalition. Retrieved from https: / /globalforestcoalition.org/wpcontent/uploads/2013/11/REDD-and-UCreport-final.pdf on February 18, 2018.

Herawati, T., Hubert, de F., Rohadi, D., Banjade, M. R., \& Fay, C. (2017). Negotiating for community forestry policy: The recognition of damar agroforests in Indonesia. In M. Cairns (Ed.), Shifting cultivation policies: balancing environmental and social sustainability (pp. 837856). Wallingford: CABI.

Herawati, T., Liswanti, N., Banjade, M. R., \& Mwangi, E. (2017). Forest tenure reform implementation in Lampung province from scenarios to action Key messages. Bogor. doi://10.17528/cifor/006418.

Herawati, T., \& Mwangi, E. (2017). Securing tenure rights for forest-dependent communities: Implementing agency surveys in Peru, Uganda, Nepal and Indonesia 
(ver 1). Center for International Forestry Research (CIFOR), Bogor. doi://10.17528/ cifor/006643.

Hidayat, H. (2016). Forest resources management in Indonesia (1968-2004) : A political ecology approach. Singapore: Springer. Retrieved from https://www.springer.com/gp/ book/9789812877444 on March 21, 2018.

Hidayat, H., Yogaswara, H., Herawati, T., Blazey, P., Wyatt, S., \& Howitt, R. (2018). Forests, law and customary rights in Indonesia: Implications of a decision of the Indonesian Constitutional Court in 2012. Asia Pacific Viewpoint, 59(3), 293-308. doi://10.1111/apv.12207.

Kusumanto, Y., \& Sirait, M. T. (2012). Community participation in forest resource management in Indonesia: Policies, practices, constraints and opportunities. Bogor. Retrieved from http://www.worldagroforestry.org/sea/ Publications/files/working paper/WP004604.pdf on March 14, 2018.

Liswanti, N., Tjoa, M,. Silaya, T., Banjade, M. R., Mwangi, E. (2017). Securing tenure rights in Maluku, Indonesia; Searching for common action. CIFOR Info Brief No 170. February 2017. Centre for International Forestry Research.

Larson, A., \& Dahal, G. (2012). Forest tenure reform: New resource rights for forest-based communities? Conservation and Society, 10(2), 77-90. doi://10.4103/0972-4923.97478.

Lee, Y., Rianti, I. P., \& Park, M. S. (2017). Measuring social capital in Indonesian community forest management. Forest Science and Technology, 13(3), 133-141. doi://10.1080/21580103.20 17.1355335.

Maharjan, K. L. (2005). Community participation in forest resource management in Nepal. Journal of Mountain Science, 2(1), 32-41. doi://10.1007/ s11629-005-0032-2.

Maryudi, A., Devkota, R. R., Schusser, C., Yufanyi, C., Salla, M., Aurenhammer, H., ... Krott, M. (2012). Back to basics: Considerations in evaluating the outcomes of community forestry. Forest Policy and Economics, 14(1), 1-5. doi://10.1016/J.FORPOL.2011.07.017.

Mendoza, G. A. (2000). Development of a methodology for selecting criteria and indicators of sustainable forest management: A case study on participatory assessment. doi://10.1007/s002670010123.
MoEF. (2016). Statistik. Kementerian Lingkungan Hidup dan Kebutanan Tabun 2015. Jakarta, Indonesia.

MoEF. (2018). The State of Indonesia's Forest 2018. (Siti Nurbaya, Ed.). The Ministry of Environment and Forestry, Republic of Indonesia.

Nugroho, H., van der Veen, A., Skidmore, A., \& Hussin, Y. (2017). Theoretical framework for spatial planning and forest management in Indonesia: securing the basic rights for adat people. Indonesian Journal of Forestry Research, 4(1), 69-83.

Pratihast, A., DeVries, B., Avitabile, V., de Bruin, S., Kooistra, L., Tekle, M., ... Herold, M. (2014). Combining satellite data and communitybased observations for forest monitoring. Forests, 5(10), 2464-2489.

Purnomo, H., Mendoza, G. A., \& Prabhu, R. (2005). Analysis of local perspectives on sustainable forest management: an Indonesian case study. Journal of Environmental Management, 74(2), 111-126. doi://10.1016/J. JENVMAN.2004.08.013.

Santika, T., Meijaard, E., Budiharta, S., Law, E. A., Kusworo, A., Hutabarat, J. A., ... Wilson, K. A. (2017). Community forest management in Indonesia: Avoided deforestation in the context of anthropogenic and climate complexities. Global Environmental Change, 46, 60-71. doi://10.1016/J. GLOENVCHA.2017.08.002.

Sellars, E. A., \& Alix-Garcia, J. (2018). Labor scarcity, land tenure, and historical legacy: Evidence from Mexico. Journal of Development Economics, 135, 504-516. doi://10.1016/J. JDEVECO.2018.07.014

Siscawati, M., Banjade, M. R., Liswanti, N., Herawati, T., Mwangi, E., Wulandari, C., ... Silaya, T. (2017). Overview of forest tenure reforms in Indonesia. Bogor: Center for International Forestry Research (CIFOR). doi.org://10.17528/cifor/006402.

Sloan, S., Campbell, M. J., Alamgir, M., Collier-Baker, E., Nowak, M. G., Usher, G., \& Laurance, W. F. (2018). Infrastructure development and contested forest governance threaten the Leuser Ecosystem, Indonesia. Land Use Policy, 77, 298-309. doi://10.1016/J. LANDUSEPOL.2018.05.043

Suharti, S. (2001). Increased community participation in forest management through the development of social forestry programmes 
in Indonesia. In Tropenbos (Ed.), The Balance between Biodiversity conservation and sustainable use of tropical rain forests (pp. 233-244). Tropenbos International, Wagenigen.

Tan, R., Wang, R., \& Heerink, N. (2018). Liberalizing rural-to-urban construction land transfers in China: Distribution effects. China Economic Review. doi://10.1016/J. CHIECO.2018.01.001.

Tiani, A. M., \& Charancle, J.-M. B. (2007). Simple criteria and indicator to uncover and negotiate local perception on sustainablity. Forests, Trees and Livelihoods, 17(1), 3-21. doi://10.1080/14 728028.2007.9752578.

Wulandari, C., \& Inoue, M. (2018). The Importance of social learning for the development of community based forest management in Indonesia: The case of community forestry in Lampung Province. Small-Scale Forestry, 17(3), 361-376. doi://10.1007/s11842-018-9392-7.
Zhang, K., \& Putzel, L. (2016). Institutional innovation and forest landscape restoration in China: Multi-scale cross-sector networking, household fiscal modernization and tenure reform. World Development Perspectives, 3, 18-21. doi://10.1016/J.WDP.2016.11.002.

Zinda, J., \& Zhang, Z. (2018). Land tenure legacies, household life cycles, and livelihood strategies in upland China. Rural Sociology, 83(1), 51-80. doi://10.1111/ruso.12164. 